\title{
MMP2-9 Cleavage of Dystroglycan Alters the Size and Molecular Composition of Schwann Cell Domains
}

\author{
Felipe A. Court, ${ }^{1}$ Desirée Zambroni, ${ }^{1}$ Ernesto Pavoni, ${ }^{1}$ Cristina Colombelli, ${ }^{1}$ Chiara Baragli, ${ }^{1}$ Gianluca Figlia, \\ Lydia Sorokin, ${ }^{2}$ William Ching, ${ }^{3}$ James L. Salzer, ${ }^{3}$ Lawrence Wrabetz, ${ }^{1}$ and M. Laura Feltri ${ }^{1}$ \\ ${ }^{1}$ Division of Genetics and Cell Biology, San Raffaele Scientific Institute, 20132 Milan, Italy, ${ }^{2}$ Institute of Physiological Chemistry and Pathobiochemistry, \\ University of Muenster, 48149 Muenster, Germany, and ${ }^{3}$ Department of Cell Biology and Neurology, and the Smilow Neuroscience Program, New York \\ University School of Medicine, New York, New York 10016
}

\begin{abstract}
Myelinating glial cells exhibit a spectacular cytoarchitecture, because they polarize on multiple axes and domains. How this occurs is essentially unknown. The dystroglycan-dystrophin complex is required for the function of myelin-forming Schwann cells. Similar to other tissues, the dystroglycan complex in Schwann cells localizes with different dystrophin family members in specific domains, thus promoting polarization. We show here that cleavage of dystroglycan by matrix metalloproteinases 2 and 9 , an event that is considered pathological in most tissues, is finely and dynamically regulated in normal nerves and modulates dystroglycan complex composition and the size of Schwann cell compartments. In contrast, in nerves of $\mathrm{Dy}^{2 j / 2 j}$ mice, a model of laminin 211 deficiency, metalloproteinases 2 and 9 are increased, causing excessive dystroglycan cleavage and abnormal compartments. Pharmacological inhibition of cleavage rescues the cytoplasmic defects of $\mathrm{Dy}^{2 j / 2 j}$ Schwann cells. Thus, regulated cleavage may be a general mechanism to regulate protein complex composition in physiological conditions, whereas unregulated processing is pathogenic and a target for treatment in disease.
\end{abstract}

\section{Introduction}

Function of many cell types depends on polarization, the formation of different anatomical, and molecular domains. Myelinating Schwann cells are highly polarized both radially and longitudinally, a configuration required for action potential propagation (Salzer, 2003). In addition, the cytoplasm outside myelin is organized into regions in which the outer cell membrane and myelin are apposed (see Fig. 2C) or cytoplasmic channels extending from perinuclear to nodal regions (Cajal bands and trabeculae) (Ramón y Cajal, 1933). These structures probably fulfill the metabolic and transport requirement of Schwann cells (Kidd et al., 1994; Court et al., 2004), which must extend up to $1 \mathrm{~mm}$ in length and produce 50-100 wraps of spiraling membrane during myelination. It has been proposed that this pattern is also required to achieve the correct length of a myelin segment (internodal length), which in turn regulates nerve conduction velocity (Court et al., 2004). We recently demonstrated that the dystrophin-gly-

Received Jan. 10, 2011; revised May 19, 2011; accepted May 31, 2011.

Author contributions: F.A.C., L.W., and M.L.F. designed research; F.A.C., D.Z., E.P., C.C., C.B., G.F., and W.C. performed research; L.S. and L.W. contributed unpublished reagents/analytic tools; F.A.C., D.Z., E.P., C.C., J.L.S., L.W., and M.L.F. analyzed data; F.A.C. and M.L.F. wrote the paper.

This work was supported by NINDS Grants R01NS045630 (M.L.F.) and R01-NS055256 (L.W.), Telethon Italia Grants GGP08021 (M.L.F.) and GGP071100 (L.W.), the European Community's Seventh Programme (FP7/20071013) under Grant Agreement HEALTH-F2-2008-201535, and Millennium Nucleus Grant P-07-011-F (F.C.). F.C. was supported by an EMBO long-term fellowship. We thank K. Campbell for DAG floxed mice and antibodies, G. Opdenakker and S. Itohara for MMP-null mice, and P. Brophy, D. Sherman, and V. Lee for antibodies.

F. A. Court's present address: Millennium Nucleus for Regenerative Biology, Faculty of Biology, P. Catholic University of Chile, 114-D, Santiago, Chile.

Correspondence should be addressed to M. Laura Feltri, San Raffaele Scientific Institute, via Olgettina 58, 20132 Milan, Italy. E-mail: feltri.laura@hsr.it.

DOI:10.1523/JNEUROSCI.0141-11.2011

Copyright $\odot 2011$ the authors $\quad 0270-6474 / 11 / 3112208-10 \$ 15.00 / 0$ coprotein complex (dystroglycan complex), containing utrophin and laminin 211, plays a role in this process (Court et al., 2009). This may explain the internodal abnormalities seen in mice and patients lacking laminin 211 in congenital muscular dystrophy 1A (Bradley and Jenkison, 1973; Di Muzio et al., 2003). The dystroglycan complex connects the cytoskeleton to extracellular matrix, and, in Schwann cells, it consists of $\alpha$ - and $\beta$-dystroglycan (DG), sarcoglycans, dystrobrevins, synthrophins, and the dystrophin family members utrophin, Dp116, and Drp2. The dystroglycan complex provides a scaffold for specific proteins required for myelin stability (Sherman et al., 2001; Cai et al., 2007; Albrecht et al., 2008), and its composition varies in different Schwann cell compartments: utrophin, Dp116, $\alpha$-dystrobrevin1, and syntrophins are in Cajal bands (Albrecht et al., 2008; Court et al., 2009), Drp2 and periaxin are in appositions (Sherman et al., 2001), and Dp116 is enriched in microvilli (Occhi et al., 2005). How the differential distribution of dystroglycan complex components is achieved is unknown. Here we provide evidence that selective proteolytic processing is a mechanism contributing to this cell polarization.

$D G$ is processed after synthesis into transmembrane $\beta$-dystroglycan ( $\beta$-DG) and extracellular $\alpha$-dystroglycan $(\alpha$-DG), which binds laminins and proteoglycans (Ibraghimov-Beskrovnaya et al., 1992; Holt et al., 2000). $\beta$-DG can be further cleaved extracellularly by matrix metalloproteinase (MMP) 2 and 9, yielding a transmembrane protein unable to bind $\alpha$-DG, therefore disrupting the linkage between the basement membrane and the cytoskeleton (Yamada et al., 2001; Zhong et al., 2006). With few exceptions, this processing has been associated with pathological conditions, including cancer invasion, autoimmune encephalomyelitis, and muscular dystrophies (Matsumura et al., 2003; Jing et al., 2004; Agrawal et al., 2006; Shang et al., 2008). 
Here we show that the composition and localization of components of the dystroglycan complex change depending on cleavage of $\beta$-dystroglycan by MMP- 2 and MMP-9 and that this is a physiological process that Schwann cells may use to remodel subcellular compartments. In contrast, excessive dystroglycan cleavage results in abnormal compartments in nerves from $\mathrm{Dy}^{2 \mathrm{j} / 2 \mathrm{j}}$ mice, an animal model of congenital muscular dystrophy $1 \mathrm{~A}$ (Bradley and Jenkison, 1973; Di Muzio et al., 2003). Inhibition of DG proteolysis restores normal compartments in myelinating Dy ${ }^{2 j / 2 j}$ cultures.

\section{Materials and Methods}

Mice. P0CreDGko and $D y^{2 j / 2 j}$ mice were reported previously (Lane et al., 1976; Feltri et al., 1999; Saito et al., 2003) and were on a C57BL/6 background. MMP-2 knock-out (KO) mice (C57BL/6) were from S. Itohara (Riken Institute, Tokyo, Japan) (Itoh et al., 1997), MMP-9 KO mice were from G. Odenakker (University of Leuven, Leuven, Belgium) (Dubois et al., 1999) (C57BL/6) and The Jackson Laboratory (Vu et al., 1998) (FVB). Experiments were approved by the San Raffaele Institutional Animal Care and Use Committee and complied with NIH guidelines.

Primary/secondary antibodies and dyes. Primary antibodies included the following: rabbit anti-Drp2 (generous gift from P. J. Brophy and D. Sherman, University of Edinburgh, Edinburgh, UK), mouse anti-tubulin (Sigma), FITC and TRITC-conjugated phalloidin (Sigma), mouse anti$\beta$-dystroglycan (43DAG/8D5; Novocastra), mouse anti-DP116 (Mandra1; Sigma), mouse anti-glycosylated $\alpha$-dystroglycan (IIH6), goat anticore $\alpha$-dystroglycan G20 (both generous gift from K. P. Campbell, University of Iowa, Iowa City, IA), rat anti-myelin basic protein (MBP) (generous gift from V. Lee, University of Pennsylvania, Philadelphia, PA), mouse anti-utrophin (NovoCastra Laboratories), mouse antiDp116 (Mandra1; Sigma), goat anti-MMP-9 (R \& D Systems), and rabbit anti-calnexin (Sigma).

Secondary antibodies included the following: goat anti-rabbit FITC or TRITC and goat anti-mouse Cy5 (Jackson ImmunoResearch), goat antimouse (Fab-specific) or goat anti-mouse (Fc-specific) HRP (Sigma), donkey anti-goat HRP (Tebu-Bio), goat anti-rabbit HRP, and DAPI (Sigma). The goat anti-mouse secondary antibodies were used to reveal the mouse anti- $\beta$-dystroglycan 43DAG/8D5 antibody (see Figs. 2-6). When using the Fab-specific or Fc-specific goat anti-mouse antibody, a nonspecific band of 25 or $55 \mathrm{kDa}$, respectively, appeared, which was present even when the primary antibody was omitted (marked with * in the figures) and represented Ig in the nerves recognized by the secondary antibody.

Western blot analysis. Sciatic nerves and dorsal root ganglia or coverslips with explants were frozen and homogenized in a metal pestle and then lysed with buffer PN1 containing $25 \mathrm{~mm}$ Tris, pH 7.4, $95 \mathrm{~mm} \mathrm{NaCl}$, $10 \mathrm{~mm}$ EDTA, 2\% SDS, $1 \mathrm{~mm} \mathrm{NaF}, 1 \mathrm{~mm} \mathrm{Na}_{3} \mathrm{VO}_{4}$, and $1 \%$ protease inhibitor cocktail (PIC) (catalog \#P8340; Sigma-Aldrich). Western blot was performed using standard techniques.

Gelatin zymography. Sciatic nerves were dissected and perineurium removed. Nerves were homogenized in $100 \mathrm{~mm}$ Tris, pH 7.4, $200 \mathrm{~mm}$ $\mathrm{NaCl}, 1 \%$ Triton X-100, 1 mm 4-(2-aminoethyl)benzenesulfonyl fluoride (AEBSF), and $1 \%$ PIC and centrifuged for $15 \mathrm{~min}$ at $4^{\circ} \mathrm{C}$. Supernatants were recovered, and proteins were quantified (BCA kit; Invitrogen). Proteins, $60 \mu \mathrm{g}$, were mixed with $3 \times$ sample buffer and loaded in an SDS gel containing $1 \mathrm{mg} / \mathrm{ml}$ pig skin gelatin (Fluka) in the running part of the gel. Samples were not boiled or treated with DTT to avoid loss of enzymatic activity. After running, the gel was washed in distilled water $\left(\mathrm{dH}_{2} 0\right)$ twice, incubated in a solution containing $2.5 \%$ Triton X-100 in $\mathrm{dH}_{2} 0$, washed, and incubated in $50 \mathrm{~mm}$ Tris, $\mathrm{pH} 7.6,5 \mathrm{~mm} \mathrm{CaCl}_{2}$, and $0.02 \%$ $\mathrm{NaN}_{3}$ at $37^{\circ} \mathrm{C}$. After two washes in $\mathrm{dH}_{2} 0$, gels were stained with Coomassie Brilliant Blue and destained until degradative, negative bands appear.

Wheat germ agglutinin pull-down. Sciatic nerves were frozen and grinded in a metal pestle. From this step, all procedures were performed at $4^{\circ} \mathrm{C}$. Nerve powders were incubated with lysis buffer B (50 mM Tris$\mathrm{HCl}, \mathrm{pH} 7.5,120 \mathrm{~mm} \mathrm{NaCl}, 1 \%$ digitonin, $0.25 \mathrm{~mm}$ AEBSF, and 1\% PIC) for $2 \mathrm{~h}$ in a rotating apparatus, lysates were centrifuged at 13,200 rpm for $30 \mathrm{~min}$, and the supernatant (input) was mixed with wheat germ agglu- tinin (WGA)-Sepharose (washed in buffer B overnight). After centrifugation, the supernatant was stored (void), and WGA-bound proteins were washed in buffer B and eluted using $0.6 \mathrm{M} \mathrm{N}$-acetyl-D-glucosamine for $5 \mathrm{~min}$ at room temperature (WGA). After spinning, eluted proteins were loaded in an SDS gel for Western blot. Although $\beta$-DG is also glycosylated, our protocol allows us to obtain a fraction rich in $\alpha$-DG.

Electron microscopy. Electron microscopy was performed as described (Wrabetz et al., 2000).

Immunofluorescence. For immunofluorescence, sciatic nerve fibers were teased and immediately stained with mild permeabilization to preserve the abaxonal subcortical Schwann cell structure as described (Court et al., 2009), with the following modification for dystroglycan complex proteins: nerves permeabilized for $5 \mathrm{~min}$ in methanol at room temperature and blocked with $1 \%$ fish skin gelatin. Dorsal root ganglia were fixed for $10 \mathrm{~min}$ in $4 \%$ paraformaldehyde and blocked/permeabilized with 5\% fish skin gelatin and $0.5 \%$ Triton X-100.

Drug injection. Intraperineurial drug injection (IL-1 $\beta, 20 \mu \mathrm{g} / \mathrm{ml}$; GM6001 ( $N$-[(2R)-2(hydroxamidocarbonylmethyl)-4-methylpantanoyl]L-tryptophan methylamide), $1 \mathrm{~mm}$ ) was performed as described (Court and Alvarez, 2000).

Rat dorsal root ganglia-Schwann cell cocultures. Primary rat dorsal root ganglia and Schwann cell cultures were prepared from embryos of 15-17 gestational days per the method described (Einheber et al., 1997).

Mouse dorsal root ganglia explants. Dorsal root ganglia were dissected from embryos of 14.5 gestational days as described previously (Nodari et al., 2007). After $3 \mathrm{~d}$, ascorbic acid $(50 \mu \mathrm{g} / \mathrm{ml})$ was added to the medium to induce myelination for 2-3 weeks, in the presence or absence of GM6001 $(4-20 \mu \mathrm{M})$ or vehicle.

Morphological analysis, f-ratio, and imaging. All images were acquired with either a spinning Nipkow disk confocal microscope (UltraVIEW; PerkinElmer Life and Analytical Sciences) using a $63 \times$ objective or with a TCS SP2 Laser Scanning Confocal microscope using a $63 \times$ objective. Images were composed using Photoshop software (Adobe Systems). Any image manipulation was equally applied to all the panels in a figure.

$f$-ratio analysis at the light (LM) and electron (EM) microscopic level was performed as described previously (Court et al., 2009). Semiquantitative estimate of dystroglycan complex proteins was performed using a mask corresponding to either Drp2 staining or actin staining using TRITC-conjugated phalloidin. The signal intensity was measured in each domain and normalized to the total intensity of the complete optic slice.

\section{Results}

\section{$\beta$-DG is present without $\alpha$-DG in Cajal bands}

We first assessed the localization of dystroglycan complex components by staining freshly isolated nerve fibers. To our surprise, $\alpha$-DG was absent in Cajal bands, whereas $\beta$-DG was present when costained in identical conditions (Fig. 1A). Staining with antibodies recognizing either the core $\alpha$-DG protein or its glycosylated epitope colocalized in patches/appositions, excluding the possibility that $\alpha$-DG was not detectable in Cajal bands because of potential differences in glycosylation that affect antibody binding (Fig. $1 B$ ). As reported (Sherman et al., 2001; Albrecht et al., 2008), the intracellular DG partners utrophin and DP116 were enriched in Cajal bands, whereas appositions contained Drp2 (Fig. 1). This is consistent with published data showing gaps in immunostaining for Drp2 and Dp116 in nerve cross-sections (Saito et al., 1999; Sherman et al., 2001; Albrecht et al., 2008). Triple staining confirmed that Drp2 and $\alpha$-DG completely colocalized in appositions, whereas $\beta$-DG was also present in Cajal bands (Fig. 2). Therefore, utrophin, Dp116, and Drp2 are not only segregated in different subcellular domains but are found with two different DGs: complete DG ( $\alpha$ and $\beta$ ) in appositions or $\beta$-DG alone in Cajal bands. Absence of $\alpha$-DG in Cajal bands does not preclude linkage to the basal lamina in these regions, because other laminin receptors such as $\alpha 6 \beta 1$ or $\alpha 6 \beta 4$ integrins are localized in Cajal bands (Fig. 1) (Nodari et al., 2008). 
The extracellular domain of $\boldsymbol{\beta}-\mathrm{DG}$ is cleaved by MMP-2/MMP-9 in Schwann cells and copurifies with different dystrophin protein family members The presence of $\beta$-DG without $\alpha$-DG in Cajal bands suggested cleavage of the extracellular domain of $\beta$-DG. In several tissues, the gelatinases MMP-2 and MMP-9 cleave $\beta$-DG in its $N$-terminal extracellular portion, releasing $\alpha$-DG (Yamada et al., 2001). We confirmed in sciatic nerves the presence of the full 43 $\mathrm{kDa}$ form of $\beta$-DG (herein referred to as $\beta-\mathrm{DG}_{43}$ ) and a smaller $31 \mathrm{kDa}$ form, which corresponds to $\beta$-DG lacking its extracellular domain $\left(\beta-\mathrm{DG}_{31}\right)$ (Yamada et al., 2001) (Fig. $2 B$, input lane). To support that cleavage of the $\mathrm{N}$ terminus of $\beta$-DG explains the absence of $\alpha$-DG in Cajal bands, we asked whether only $\beta-\mathrm{DG}_{43}$ copurified with glycosylated $\alpha$-DG (present in appositions only) after pull-down of nerve lysates using WGA. As expected, WGA pulled down $\alpha$-DG from nerves (Fig. 2B). Associated with the WGA fraction was $\beta-\mathrm{DG}_{43}$ but not cleaved $\beta-\mathrm{DG}_{31}$ (Fig. $2 \mathrm{~B}$ ). In contrast, the void fraction contained $\beta-\mathrm{DG}_{31}$ but little or no $\beta-\mathrm{DG}_{43}$, strongly suggesting that $\beta$-DG in Cajal bands is cleaved. From the immunolocalization, we expect that components of the dystroglycan complex in appositions (Drp2, $\alpha$-DG, and $\beta$-DG $\mathrm{DG}_{43}$ ) would copurify in the WGA fraction, whereas components of the dystroglycan complex in Cajal bands (utrophin, Dp116, and $\beta-\mathrm{DG}_{31}$ ) would be absent. Indeed, only Drp2 was in the WGA fraction, whereas utrophin and Dp116 were only in the void fraction with $\beta-\mathrm{DG}_{31}$ (Fig. $2 B$ ). Drp2 was also detected in the void, probably representing Drp2 protein not efficiently pulled down. These results suggest that, in appositions/ patches, the dystroglycan complex is composed of $\alpha$-DG, $\beta-\mathrm{DG}_{43}$, and Drp2. In contrast, the void fraction corresponds to Cajal bands and contains the cleaved form of $\beta$-DG $\left(\beta-\mathrm{DG}_{31}\right)$, utrophin, and Dp116. Although the reagents available preclude a direct visualization of $\beta-\mathrm{DG}_{31}$ independently of $\beta-\mathrm{DG}_{43}$ in Cajal bands, this is consistent with previous data showing preferential binding of Dp116 to $\beta-\mathrm{DG}_{31}$ in peripheral nerves (Saito et al., 1999).

According to this model, the "Cajal bands dystroglycan complex" should be more tightly linked to the actin cytoskeleton than the "appositions/patches dystroglycan complex" because the former associates with utrophin, the only dystrophin family member with an actin-binding motif, and because most of the cytoskeleton is in Cajal bands (Court et al., 2009). We tested this by asking which detergent was able to extract $\beta-\mathrm{DG}_{43}$ and $\beta-\mathrm{DG}_{31}$ in nerves. As expected, Triton X-100 (a detergent able to solubilize cytoskeletal proteins) was able to extract both $\beta-\mathrm{DG}_{43}$ and $\beta-\mathrm{DG}_{31}$, whereas the milder detergent digitonin was only able to extract full $\beta$-DG $\mathrm{DG}_{43}$ (Fig. $2 D$ ). Thus, $\beta-\mathrm{DG}_{31}$, even if is not linked to the extracellular matrix, is more tightly bound to the cytoskeleton.

Together, the results point to the model in Figure $2 C$. The most important aspect is that cleavage of $\beta$-DG with shedding of $\alpha$-DG takes place in the subcellular Cajal bands domain and it associates with specific dystrophin-related proteins. This can contribute to creation or maintenance of compartments with

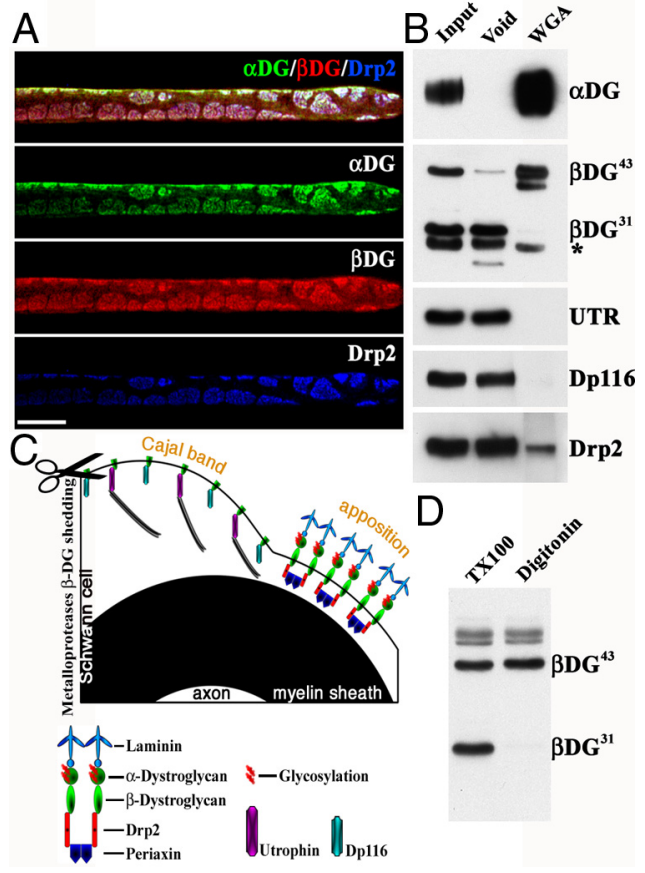

Figure 2. $\quad \beta-D G_{43}$ and $\beta-D G_{31}$ copurify with different intracellular partners. $\boldsymbol{A}$, Triple immunofluorescence staining of teased fibers from adult mouse sciatic nerves using antibodies against $\alpha$-DG (green), $\beta$-DG (red), and Drp2 (blue). Confocal microscopy was used to detect the signal from the most superficial layer of the Schwann cell plasma membrane. Costaining shows colocalization of Drp2 and $\alpha$-DG in apposition/patches and absence of $\alpha$-Dg in Cajal bands. Scale bar, $10 \mu \mathrm{m}$. $\boldsymbol{B}$, WGA pull-down from adult sciatic nerves. Most $\beta-D G_{43}$ is detected in the WGA fraction, whereas $\beta-D_{31}$ is only present in the void fraction ( ${ }^{*}$ marks an Ig nonspecific band recognized by the secondary antibody; see Material and Methods). The only dystrophin in the WGA fraction is Drp2, utrophin (UTR), and Dp116 are in the void fraction. C, Proposed model of the localization of different dystroglycan complexes in Schwann cells. $\beta-D G_{31}$ is cleaved by MMP-2/9 (scissor) and associates with utrophin or Dp116 in Cajal bands. Uncleaved $\beta-\mathrm{DG}_{43}$ associates with $\alpha$-DG extracellularly, Drp2 and periaxin intracellularly, and localizes at appositions. $\boldsymbol{D}$, Western blot of adult sciatic nerve shows extraction of $\beta-D G_{31}$ with $1 \%$ Triton X-100 but not with $1 \%$ digitonin. 


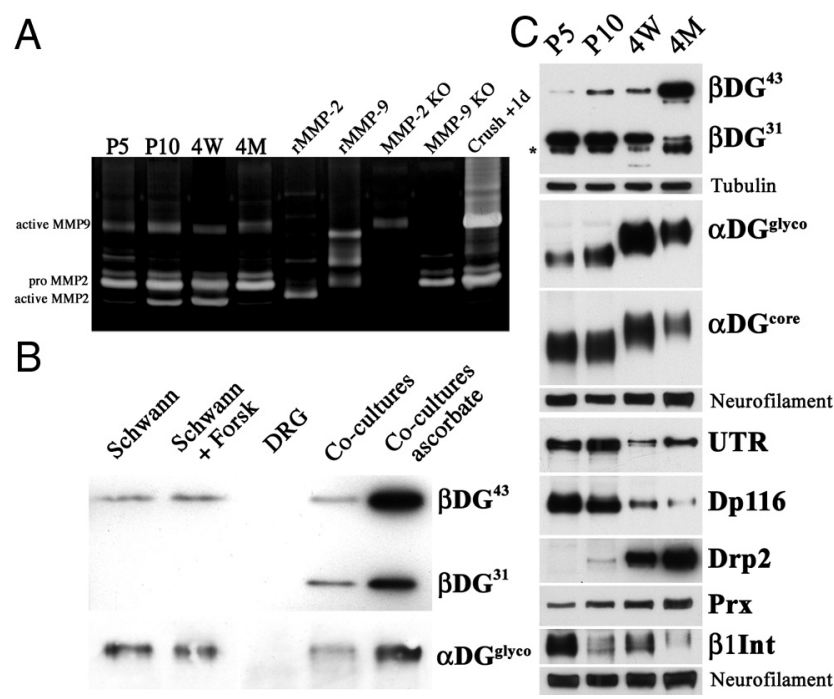

Figure 3. Expression of $D G$ complex proteins during development correlates with $\beta$-DG processing. $A$, Gelatin gel zymography of sciatic nerves shows active MMP-2 and MMP-9 during development. Controls, Recombinant MMP-2 and MMP-9 (rMMP-2/9), nerve from MMP-2-and MPP-9-deficient mice or $1 \mathrm{~d}$ after crush injury. $\boldsymbol{B}$, Cleavage of $\beta$-DG is induced by axonal contact in rat dorsal root ganglia-Schwann cell cocultures. $\beta$-DG is cleaved when Schwann cells are cocultured with neurons; addition of ascorbic acid increased total $\beta$-DG expression. C, Western blot of sciatic nerves. Before compartments form in Schwann cells (P5), $\beta$-DG is mostly cleaved $\left(\beta-D G_{31}\right)$. When appositions appear (P10) and progressively grow [4 weeks (4W) to 4 months $(4 M)]$, the uncleaved $\beta-D G_{43}$ form increases and $\beta-D G_{31}$ decreases. The abundance of the proposed partners (utrophin and DP116 for $\beta D G_{31}$; Drp2, periaxin, and $\alpha-D G$ for $\beta-D G_{43}$ ) changes accordingly. $\alpha$-DG also shows a developmental increase from $90-100$ to $120-130$ $\mathrm{kDa}$ as a result of glycosylation. different molecular composition that might fulfill Schwann cell metabolic, transport, or signaling needs.

Cleavage of $\boldsymbol{\beta}$-DG by gelatinases is developmentally regulated during myelination and correlates with the expression of the corresponding dystrophin family member

We wondered whether gelatinase activity and cleavage of $\beta$-DG were regulated in development. We showed previously that compartmentalization of the Schwann cell cytoplasm in vivo starts at approximately P10, with formation of an actin scaffold around nascent appositions (Court et al., 2009). We found low levels of MMP-9 throughout development, upregulated after nerve injury, as reported (La Fleur et al., 1996). Comparison to the size of MMP-9 in injured nerves suggests that the detected MMP-9 is active (Fig. $3 A$ ). In contrast, active MMP-2 is detected at P10 and 4 weeks but not early in development (P5) or in mature nerves (Fig. 3A). Because axons regulate most aspects of Schwann cell differentiation, we next asked whether dystroglycan cleavage was influenced by axonal contact. Purified rat dorsal root ganglia neurons do not express dystroglycan, whereas purified rat Schwann cells show predominantly uncleaved $\beta-\mathrm{DG}_{43}$ (Fig. $3 B$ ) even if $\beta-\mathrm{DG}_{31}$ appears at longer exposures (data not shown). Contact with dorsal root ganglia neurons significantly increased the cleaved $\beta-\mathrm{DG}_{31}$ form (Fig. $3 B$ ). We next analyzed $\beta$-DG cleavage in developing sciatic nerve. At P5, when cytoplasm compartmentalization has not begun and no Drp2-positive patches are detected (Court et al., 2009), the predominant $\beta$-DG is cleaved $\beta-\mathrm{DG}_{31}$. As appositions form (P10) and enlarge (4 weeks), full-length $\beta-\mathrm{DG}_{43}$ increases and cleaved $\beta-\mathrm{DG}_{31}$ decreases (Fig. $3 C$ ), in agreement with the idea that appositions are formed by intact $\beta-\mathrm{DG}_{43}$. Proteins proposed to associate with either intact or cleaved $\beta$-DG follow a similar trend: utrophin and Dp116 are highly expressed at P5 and decrease after appositions form (P10). In contrast, Drp2 is upregulated in parallel with the increase in $\beta-\mathrm{DG}_{43}$ when appositions form and increase in size. $\alpha$-DG expression does not change during development but its glycosylation does, a modification that might modulate the susceptibility of $\beta$-DG to MMP cleavage. These findings reveal a correlation between the compartment that predominates at each developmental stage and their associated dystroglycan complex components. Our results suggest that MMP cleavage of $\beta$-DG may be directly involved in cytoplasmic compartmentalization by regulating the amount and composition of dystroglycan complex required for the formation of each cytoplasmic domain.

Modulation of MMP activity in nerves leads to modification of Schwann cell compartments

Selective $\alpha$-DG shedding in Cajal bands may regulate formation and maintenance of compartments in Schwann cells, because this requires linkage between the cortical cytoskeleton and the basement membrane (Court et al., 2009). To ask
Figure 4. MMPs cleave $\beta$-DG in Schwann cells and modifies compartments. $A$, Western blot of $\beta$-DG in adult sciatic nerves injected with saline, the MMP activator IL-1 $\beta(20 \mu \mathrm{g} / \mathrm{ml})$, or the MMP inhibitor GM6001 (1 mM). MMP activation increases, whereas MMP inhibition decreases, $\beta$-DG ${ }_{31}$ in nerves. $\boldsymbol{B}, \mathrm{GM} 6001$ increases Drp2 expression, whereas utrophin (UTR) disappears. C, The proteasome inhibitor MG132 increases $\beta-\mathrm{DG}_{31}$. D, Immunofluorescence on teased fibers from nerves $24 \mathrm{~h}$ after injection stained for Drp2 and FITC-phalloidin. Activation of MMPs with IL-1 $\beta$ (middle) decreases the intensity and definition of Drp2positive patches. In contrast, MMPs inhibition using GM6001 increases Drp2 patches size, with longitudinal fusion of patches (bottom fiber). 
whether manipulation of MMP activity in vivo leads to changes in compartments, we injected the MMP-activating recombinant protein IL- $1 \beta$ (Wu et al., 2009) or the general MMP inhibitor GM6001 into the endoneurium of adult mice. Injection of IL-1 $\beta$ quickly increases the ratio of $\beta-\mathrm{DG}_{31}$ to $\beta-\mathrm{DG}_{43}$, an effect that is reversed by $48 \mathrm{~h}$ (Fig. $4 \mathrm{~A}$ ). Conversely, inhibition of MMP activity by GM6001 leads to depletion of $\beta-\mathrm{DG}_{31}$ (Fig. $4 A$ ). Increasing the relative amount of $\beta-\mathrm{DG}_{31}$ by IL- $1 \beta$ injection leads to a reduction of the definition and intensity of Drp2 staining in patches. Conversely, MMP inhibition results in increased patch size with fusion in the longitudinal orientation (Fig. 4D). Western blot analysis confirmed that inhibition of DG cleavage resulted in increased Drp2 protein levels after injection (Fig. 4B). Conversely, inhibition of shedding results in decreased utrophin content (Fig. $4 B$ ), as expected from the existence of different dystroglycan complex independently regulated by cleavage of $\beta$-DG. Thus, acute modulation of MMP activity by a single in vivo injection in nerves dynamically regulates $\beta$-DG cleavage, the amount of different dystroglycan complex, and the size of subcortical cytoplasmic compartments in Schwann cells.

One surprising aspect of this experiment was its short time frame. Cleaved $\beta-\mathrm{DG}_{31}$ disappeared within $2 \mathrm{~h}$, and this translated into a rapid increase in steady-state levels of Drp2 and to an increase in patches/apposition size. The rapid disappearance of $\beta$-DG $\mathrm{G}_{31}$ suggested degradation. When GM6001 was injected with the general proteasomal inhibitor MG132 (carbobenzoxy-L-leucyl-Lleucyl-L-leucinal) (Jensen et al., 1995), $\beta$-DG $\mathrm{DG}_{31}$ was still detectable $1 \mathrm{~h}$ after injection (Fig. 4C). MG132 also increased the amount of $\beta-\mathrm{DG}_{31}$ normally present in sciatic nerve, suggesting that the proteasome constitutively degrades the $\beta-\mathrm{DG}_{31}$ that is produced in physiological conditions.

These results indicate that the ratio between the transmembrane dystroglycan forms $\beta-\mathrm{DG}_{31} / \beta-\mathrm{DG}_{43}$, which is regulated by endogenous gelatinase activity, dynamically regulate compartments in the Schwann cell cytoplasm.

\section{Absence of MMP-2 and MMP-9 in vivo alters Schwann cell compartmentalization}

$\beta$-DG cleavage appears to play a role in the dynamic regulation of cytoplasmic compartments. To investigate whether this regulation also has long-term effects, we analyzed mice lacking MMP-9, MMP-2, or both. In adult mutant nerves, cleavage of $\beta$-DG was inhibited in double-null nerves, decreased in MMP-2-null nerves, and variable in MMP-9-null nerves (Fig. 5 and data not shown). Compartmentalization of the Schwann cell cytoplasm was quantified as the previously described ratio between the Schwann cell membrane found above Cajal bands and above appositions on electron-microscopy samples (f-ratio ${ }^{\mathrm{EM}}$ ) or above Cajal bands and Drp2-positive patches on immunostained fibers $\left(f\right.$-ratio $\left.{ }^{\mathrm{LM}}\right)$ (Court et al., 2009). The $f$-ratio is a constant of 1-1.5 in mature myelinated fibers of any caliber, and it is high when appositions are too small as a result of laminin 211 or dystroglycan deficiency (Court et al., 2009). In one (Bergers et al., 1998) of two independently generated strains of MMP-9 null mice, appositions were larger and the $f$-ratio decreased (Fig. 5A), whereas in a second strain (Vu et al., 1998), f-ratio was not decreased (data not shown). In mice lacking MMP-2 and both MMP-2 and MMP-9, $f$-ratio was also decreased (Fig. $5 A$ ). Thus, the absence of MMP-2 and MMP-9 causes a longterm reduction in the size of Cajal bands.

\section{Increase in $\beta$-DG cleavage underlies the defect in $\mathrm{Dy}^{2 \mathrm{2} / 2 j}$ nerve fibers}

$\beta$-DG proteolysis by MMP-2/9 appears as a finely tuned process that maintains the correct balance between compartments in Schwann cells. We next investigated whether unregulated, prolonged activation of MMP-2 and MMP-9 as seen in many peripheral neuropathies (Shubayev and Myers, 2000; Mirowska and Czlonkowska, 2001) can disrupt this regulatory mechanism and negatively affect the architecture of remyelinating fibers. Excessive $\beta$-DG cleavage resulting in decreased dystroglycan complex available to form appositions may explain the disrupted Drp2 patches, wider Cajal bands (higher $f$-ratio), and decreased internodal lengths described in nerves of $\mathrm{Dy}^{2 j / 2 j}$ mutants (Court et al., 2009). To test this, we evaluated MMP-2/9 activity in $\mathrm{Dy}^{2 j / 2 j}$ roots (Fig. $6 \mathrm{~B}$ ) and nerves (data not shown) and showed that it is indeed increased. MMP-9 protein expression was also increased in Dy ${ }^{2 j / 2 j}$ (Fig. 6C). Next we analyzed the proportion of fulllength and cleaved $\beta$-DG and found an increase in cleaved $\beta$-DG $G_{31}$ in $D^{2 j / 2 j}$ nerve lysates (Fig. $6 A$ ). To ask whether this was responsible for the disruption of appositions, we inhibited MMPs during myelination in vitro and asked whether we could rescue the phenotype of $\mathrm{Dy}^{2 j / 2 j}$ Schwann cells. We used dorsal root ganglia explants from $\mathrm{Dy}^{2 \mathrm{j} / 2 j}$ and $\mathrm{Dy}^{2 j /+}$ mice embryos and induced myelination in the presence of the MMP inhibitor GM6001. 

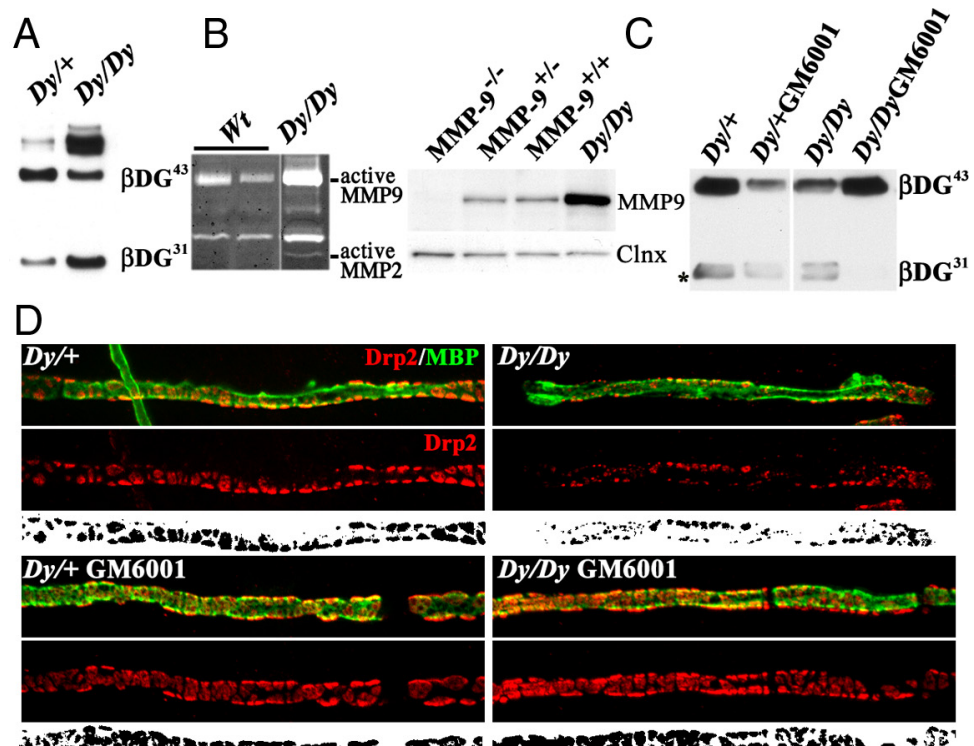

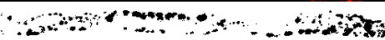
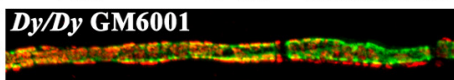

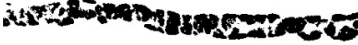

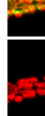

E

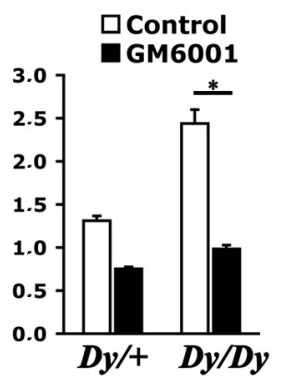

f-ratio $^{\mathrm{LM}}=\frac{\text { Area of Cajal-bands }}{\text { Area patches }}$

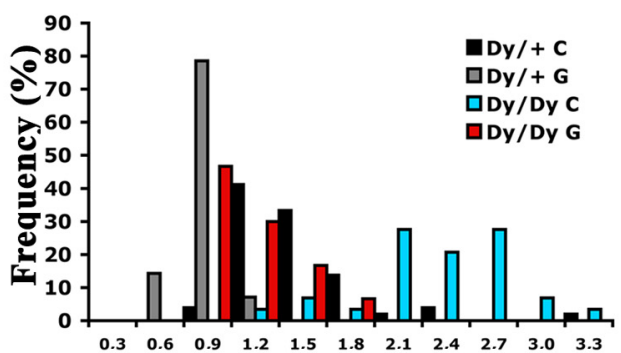

Figure 6. Inhibition of excessive DG proteolysis restores compartmentalization defects in $D y^{2 j / 2 j}$ Schwann cells. $\boldsymbol{A}-\boldsymbol{C}$, Western blots, C gelatin zymography. $\boldsymbol{A}$, More $\beta$-DG cleavage in Dy ${ }^{2 j / 2 j}$ sciatic nerves. $\boldsymbol{B}$, MMP-2 and MMP-9 are hyperactive in roots from Dy ${ }^{2 j / 2 j}$ mice. C, MMP-9 is overexpressed in Dy ${ }^{2 j / 2 j}$ sciatic nerve extracts. Calnexin (Clnx) is used as a loading control. $C$, Dorsal root ganglia explants from $D y^{2 j /+}$ and Dy ${ }^{2 j / 2 j}$ embryos myelinating in the presence or absence of the MMP inhibitor GM6001. $\beta-D G_{31}$ is decreased after GM6001 treatment. Asterisk marks a nonspecific band. D, Dy ${ }^{2 j /+}$ and Dy ${ }^{2 j / 2 j}$ explants stained with antibodies against Drp2 (red) and MBP (green). Bottom panels show the Drp2 signal above an arbitrary threshold in black and white (for details, see Court et al., 2009). Dy ${ }^{2 j / 2 j}$ Schwann cells form smaller Drp2-positive patches, and this is prevented by GM6001. Scale bar, $10 \mu \mathrm{m} . \boldsymbol{E}, \boldsymbol{F}$, Quantitative analysis of dorsal root ganglia compartments ( $\boldsymbol{E}$, mean $f$-ratio, calculated as cytoplasmic area/DRP2 patches area, as described by Court et al., 2009; $\boldsymbol{F}$, distribution of $f$-ratios in individual Schwann cells) show that GM6001 inhibition increases patches and reduces Cajal bands ( $n=4$ explants for each genotype and treatment; ${ }^{*} p<0.0001$ by Student's $t$ test; error bars indicate SEM). WT, Wild type.

Cleavage of $\beta$-DG was inhibited in explants of both genotypes treated with GM6001 (Fig. 6C). Myelin segment formed in vitro and visualized with MBP antibodies were costained with Drp2. As in vivo (Court et al., 2009), Dy ${ }^{2 j / 2 j}$ Schwann cells have smaller Drp2 patches cells, larger Cajal bands, and higher $f$-ratio than heterozygous Schwann (Fig. 6D,E). Of note, inhibition of MMP activity increased patches size and reduced Cajal bands and $f$-ratio in both $D y^{2 j / 2 j}$ and Dy ${ }^{2 j /+}$ Schwann cells (Fig. 6D,E). Thus, the increased $f$-ratio in $D y^{2 j / 2 j}$ Schwann cells was normalized after MMP inhibition and reduced $\beta$-DG cleavage.

Elongation defects in $\mathrm{Dy}^{2 \mathrm{j} / 2 j}$ Schwann cells are partially rescued by MMP inhibition

Internodal lengths are reduced in $\mathrm{Dy}^{2 \mathrm{j} / 2 j}$ animals and MDC1A (merosin-deficient Congenital Muscular Dystrophy 1A) patients (Jaros and Jenkison, 1983; Di Muzio et al., 2003; Court et al., 2009). In several, but not all, instances (Court et al., 2004, 2009; Triolo et al., 2009), defective cytoplasmic compartmentalization (smaller appositions/larger Cajal bands) was associated with reduced internodal length. We thus asked whether inhibition of DG cleavage and normalization of compartments in $\mathrm{Dy}^{2 \mathrm{j} / 2 j}$ Schwann cells also restores internodal lengths. We first confirmed that, even in myelinating explants, Dy ${ }^{2 j / 2 j}$ internodal lengths were shorter than those in $\mathrm{Dy}^{2 \mathrm{j} /+}$ Schwann cells (Fig. $7 A, B$ ). When MMP activation was inhibited, Dy ${ }^{2 j / 2 j}$ myelin segments increased in length by $23 \%$, even if they did not reach the length of wild-type internodes (Fig. $7 A, B$ ), indicating that reducing MMP activation in this pathological context improves Schwann cell elongation.

\section{Discussion}

Protein polarization in specific cell domains is crucial for cell function. In myelinated nerve fibers, several specialized domains are required for fast propagation of action potentials. The cytoplasm and membrane outside myelin in the peripheral nervous system are compartmentalized into two domains characterized by the expression of different dystroglycan complex. Here we show that this differential distribution and the size of these domains depend on $\beta$-DG cleavage by MMP-2 and MMP-9 (Fig. 8). Modulation of MMP activity quickly remodels subcellular domains in physiological situations. In contrast, during a peripheral neuropathy, excessive and unregulated $\beta$-DG cleavage causes disruption of cytoplasmic domains. Importantly, inhibition of $\beta$-DG cleavage is able to restore the normal domain organization of Schwann cells in vitro. Our results present a novel mechanism regulating both normal and abnormal subcellular polarization, dependent on physiological cleavage of $\beta$-DG by MMP-2 and MMP-9.

MMP-mediated $\beta$-DG cleavage leads to spatially distinct dystroglycan complex in Schwann cells

Several tissues in addition to muscle contain dystroglycan complexes with tissue-specific components and precise subcellular distribution (Haenggi and Fritschy, 2006). The dystroglycan complexes act as a scaffold for segregating functional proteins into specific cellular subdomains. Examples are aquaporin 4 at the astrocytic end feet (Neely et al., 2001), Kir4.1 potassium channels near synapses (Connors et al., 2004; Bragg et al., 2006), aquaporin 4 and neuronal nitric oxide synthase in sarcolemma (Adams et al., 2008), acetylcholine receptors at neuromuscular junctions (Grady et al., 2000), and laminins and polarity proteins in mammary epithelia (Weir et al., 2006). Similarly, in Schwann cells, the dystroglycan complex with Drp2 localizes periaxin in appositions possibly to bind the outer myelin wrap, whereas the dystroglycan complex with utrophin, Dp116, dystrobrevin, and syntrophins in Cajal bands localizes the ABCA1 cholesterol trans- 

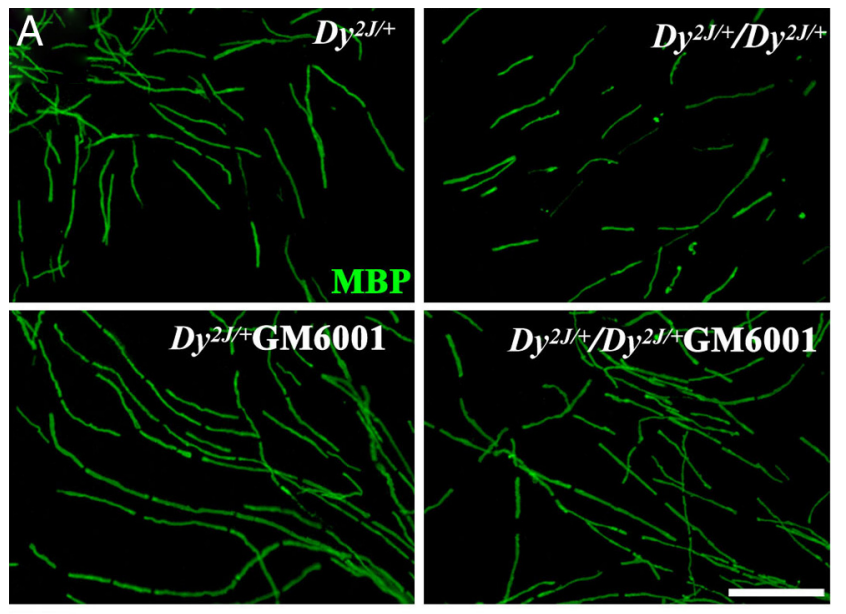

B

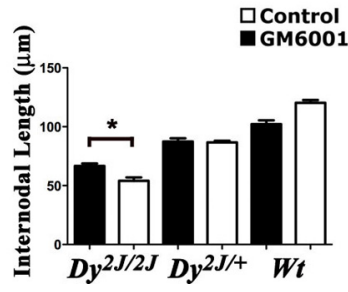

Figure 7. Shorter internodes of $\mathrm{Dy}^{2 j / 2 j}$ Schwann cells are partially rescued by MMP inhibition. DRG explants from wt, $\mathrm{Dy}^{2 j /+}$, and $\mathrm{Dy}{ }^{2 j / 2 j}$ embryos were treated during myelination with the MMP-inhibitor GM6001 and stained with an antibody against MBP (green). A, In vitro, internodal lengths of Dy ${ }^{2 j / 2 j}$ Schwann cells are smaller than wild-type (Wt) and Dy ${ }^{2 j /+}$, but continuous MMP inhibition increases length of internodes in Dy ${ }^{2 / 2 j}$. Scale bar, $100 \mu \mathrm{m}$. In $\boldsymbol{B}$, the mean internodal length for each genotype and treatment are plotted, respectively (at least 10 explants for each genotype and treatment were used; ${ }^{*} p<0.0001$, by Student's $t$ test; error bars indicate SEM).

porter (Albrecht et al., 2008). We show that $\beta$-DG cleavage changes the relative amount of these spatially distinct complexes and the size of the domain in which they reside.

An unresolved question is how $\beta$-DG cleavage regulates the localization and composition of these complexes. The rapid increase in Drp2 protein seen by Western blot after inhibition of $\beta$-DG cleavage likely reflects an increase in protein stabilization after linkage within a stable complex. The concomitant fast decrease in utrophin and $\beta-\mathrm{DG}_{31}$, the latter delayed by proteasome inhibition, suggests that active and regulated degradation of the whole dystroglycan complex located in Cajal bands is taking place constitutively. Indeed dystroglycan complex components are degraded by the proteasome (Bonuccelli et al., 2003; Gazzerro et al., 2010). $\beta$-DG shedding could also favor lateral movement of $\beta-\mathrm{DG}_{31}$ and association with $\mathrm{Dp} 116$ / utrophin in Cajal bands, similar to the way cleavage of the $\alpha / \beta$-DG precursor changes its affinity for laminin binding (Akhavan et al., 2008 ). Finally, the rate of $\beta$-DG cleavage may vary depending on the association with other protein(s) (Singh et al., 2004) that also direct targeting to either appositions or Cajal bands. Drp2 is a good candidate because it appears in development after utrophin and Dp116, is targeted to future appositions (regions free of actin) (Court et al., 2009), and may render $\beta$-DG less cleavable or less accessible to MMPs in appositions. It is also known that Drp2 in parallel binds a basic domain of periaxin that contain a nuclear localization signal in embryonic Schwann cells (Sherman and Brophy, 2000). Thus, Drp2 appearance in development may trigger formation of appositions by sequestering periaxin from its nuclear localization and by linking it to the abaxonal membrane through the dystroglycan complex (Wrabetz and Feltri, 2001).

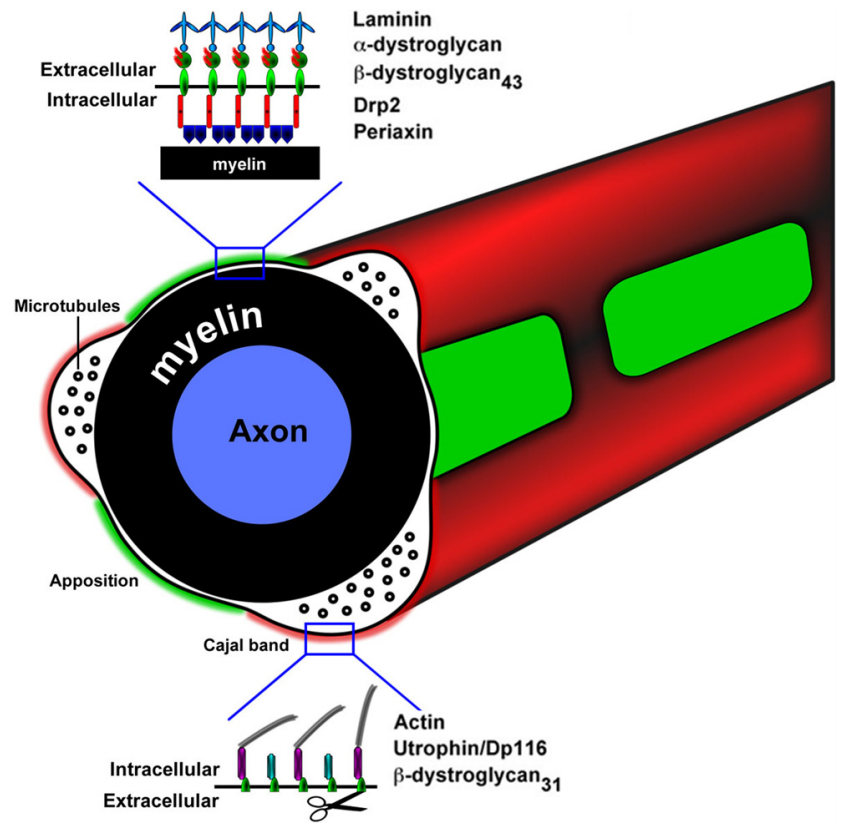

Figure 8. Schematic representation of Schwann cell abaxonal domains and their molecular composition. Appositions are formed by a complex consisting of $\alpha$-DG, full-length $\beta-\mathrm{DG}_{43}$, Drp2, and periaxin. In contrast, in Cajal bands, $\beta$-DG is cleaved by MMP-2 and MMP-9, $\alpha$-DG is shed, and the resulting $\beta-D G_{31}$ is found with utrophin and Dp116 and in part degraded by the proteasome. Utrophin can bind actin and possibly organizes the Cajal bands cytoskeleton. Linkage to the basal lamina in Cajal bands is ensured by other laminin receptors found in this location, such as $\alpha 6 \beta 4$ and $\alpha 6 \beta 1$ integrins.

Independently of the mechanism, because altering $\beta$-DG cleavage rapidly changes the amount of dystroglycan complex proteins and the size of cellular domains, we propose that this mechanism represents a dynamic way to regulate the sorting of functional proteins depending on the mechanic or metabolic requirement of myelinating cells.

Physiological function of $\boldsymbol{\beta}$-DG cleavage and $\boldsymbol{\alpha}$-DG shedding One important finding in this study is that MMP-dependent dystroglycan complex shedding is a physiological event that takes place during normal development and in mature fibers in vivo. This extends recent work showing that MMP-9 cleaves $\beta$-DG in CNS synapses in response to neuronal activity (Michaluk et al., 2007 ) and supports the idea that $\beta$-DG may have functions independent from $\alpha$-DG (Moore and Winder, 2010). Both full $\beta-\mathrm{DG}_{43}$ and cleaved $\beta-\mathrm{DG}_{31}$ are present in normal sciatic nerves and are spatially segregated, suggesting that MMP-dependent cleavage of $\beta$-DG is a constitutive process. Until recently, the dystroglycan complex was regarded mainly as linker between the extracellular matrix and the cytoskeleton, because this characteristic is required for important dystroglycan complex functions such as muscle integrity. Indeed, in normal muscle and brain, $\beta-\mathrm{DG}_{31}$ is absent and only appears in pathologies such as muscular dystrophies, cancer, or inflammation in which it is believed to represent disintegration of the dystroglycan complex (Losasso et al., 2000; Yamada et al., 2001; Matsumura et al., 2003; Singh et al., 2004; Agrawal et al., 2006; Zhao et al., 2010). In contrast, we show that, in Schwann cells, although increased $\beta$-DG cleavage is detrimental, regulated $\beta$-DG is physiological and $\beta-\mathrm{DG}_{31}$ may function as a truncated receptor. We find $\beta-\mathrm{DG}_{31}$, utrophin, and Dp116 in Cajal bands without $\alpha$-DG linkage to extracellular ligands, and previous data showed that utrophin persists in lysates of nerves lacking Schwann cell dystroglycan (Saito et al., 2003). 
Both utrophin and $\beta$-DG can bind actin and plectins (Chen et al., 2003; Rezniczek et al., 2007), whereas $\beta$-DG binds vinculin (Thompson et al., 2010). Small Drp2 patches/ultrastructural appositions can form in DG-null mice, and utrophin itself is required for proper cytoplasmic compartmentalization (Court et al., 2009). Together, these data support the idea that members of the dystroglycan complex such as utrophin can function independently of $\alpha$-DG, either uncoupled from the plasmalemma and the basal lamina or by linking the membrane through other receptors (Bozzi et al., 2009; Moore and Winder, 2010). This would add dystroglycan to the list of receptors whose function and localization depends on cleavage (Kopan and Ilagan, 2009) and to the list of MMP substrates whose biological function changes after cleavage (for review, see Page-McCaw et al., 2007). Another important question is whether the shed $\alpha$-DG, which is known to be released to the extracellular milieu (Herzog et al., 2004 ), or the cleaved extracellular portion of $\beta$-DG can function as bioactive peptides as it happens for other extracellular molecules such as collagen XVIII/endostatins (O’Reilly et al., 1997).

\section{Timescale of DG cleavage and the remodeling of Schwann cell compartments}

The rapid changes in protein level and in the size of cytoplasmic compartments after acute manipulation of $\beta$-DG cleavage were surprising. Drp2 and utrophin protein levels changed rapidly after pharmacological inhibition of gelatinases. The increase of $\beta$-DG ${ }_{31}$ after proteasome inhibition suggests that $\beta$-DG cleavage occurs constitutively and that $\beta-\mathrm{DG}_{31}$ is rapidly degraded. Finally, mice lacking MMP-2 and MMP-9 had increased size of appositions. These data suggest that abaxonal cytoplasmic compartments in Schwann cells are quickly remodeled by metalloproteinases, possibly in response to mechanic or metabolic requirements. Additional experiments will be required to explore this intriguing possibility.

\section{Increased $\beta$-DG cleavage in pathological conditions leads to Schwann cell compartmentalization defects}

MMP-2 and MMP-9 activity are increased in many pathological situations, especially if they trigger an inflammatory response. In peripheral nerves, for example, MMP-2 and MMP-9 are produced by Schwann cells and infiltrating macrophages after nerve injury or inflammatory neuropathies and cause neuropathic pain. In dystrophic $\mathrm{Dy}^{2 j / 2 j}$ mice, increase in MMP-2 and MMP-9 activity is likely also directly linked to defective extracellular matrix assembly, through its effect on integrins and urokinase plasminogen activator (La Fleur et al., 1996; Kherif et al., 1998; Ferguson and Muir, 2000; Sottile, 2004; Shubayev et al., 2006; Chattopadhyay et al., 2007; Zhao et al., 2010).

It has been long established that myelin segments formed after remyelination are shorter than normal (Hiscoe, 1947). We provide evidence that this could potentially be caused by excessive cleavage of $\beta$-DG and formation of defective compartments, which has been linked to internodal length. The function of Schwann cell abaxonal compartments is not clearly understood. One hypothesis that has been proposed is that Cajal bands formation may aid microtubule-based transport and permit normal elongation of Schwann cells. Indeed, mice lacking appositions (periaxin-null mice, Schwann cell dystroglycan-null mice, laminin 211-null mice, utrophin-null mice) all have short internodes (Court et al., 2004, 2009). However, mice lacking appositions can also have normal internodal length (Triolo et al. 2009). Albeit open because of lack of appositions, Cajal bands are still present in this instance, suggesting that other attributes of the
Cajal bands channels, such as microtubule organization and segregation of molecules in the proper compartments by the dystroglycan complexes, are the important factors for polarized trafficking and regulation of internodal length. Indeed, we show that defective compartments and internodal length can be ameliorated after correction of MMP activity. Because the in vitro system lacks macrophages, this suggest that Schwann cells release MMP-2 and MMP-9 as part of a cell-autonomous mechanism regulating cytoplasmic compartmentalization. In addition to the increase in MMP-9 expression in Dy ${ }^{2 j / 2 j}$ nerves, the dystroglycan complex may also be more susceptible to cleavage in $\mathrm{Dy}^{2 \mathrm{j} / 2 j}$ nerves. A possible mechanism is lack of the laminin 211 extracellular binding partner that destabilizes the dystroglycan complex and exposes it to MMP-dependent proteolytic processing. Similarly, perlecan (Herzog et al., 2004) and sarcoglycans might mask the MMP cleavage site on $\beta$-DG (Roberds et al., 1993; Straub et al., 1998; Yamada et al., 2001). Inhibition of MMP-2/9 in all these situations may help to reserve the integrity of the dystroglycan complex and may explain in part the beneficial effect recently demonstrated in mdx mice (Li et al., 2009).

\section{References}

Adams ME, Tesch Y, Percival JM, Albrecht DE, Conhaim JI, Anderson K, Froehner SC (2008) Differential targeting of nNOS and AQP4 to dystrophindeficient sarcolemma by membrane-directed alpha-dystrobrevin. J Cell Sci 121:48-54.

Agrawal S, Anderson P, Durbeej M, van Rooijen N, Ivars F, Opdenakker G, Sorokin LM (2006) Dystroglycan is selectively cleaved at the parenchymal basement membrane at sites of leukocyte extravasation in experimental autoimmune encephalomyelitis. J Exp Med 203:1007-1019.

Akhavan A, Crivelli SN, Singh M, Lingappa VR, Muschler JL (2008) SEA domain proteolysis determines the functional composition of dystroglycan. FASEB J 22:612-621.

Albrecht DE, Sherman DL, Brophy PJ, Froehner SC (2008) The ABCA1 cholesterol transporter associates with one of two distinct dystrophinbased scaffolds in Schwann cells. Glia 56:611-618.

Bergers G, Hanahan D, Coussens LM (1998) Angiogenesis and apoptosis are cellular parameters of neoplastic progression in transgenic mouse models of tumorigenesis. Int J Dev Biol 42:995-1002.

Bonuccelli G, Sotgia F, Schubert W, Park DS, Frank PG, Woodman SE, Insabato L, Cammer M, Minetti C, Lisanti MP (2003) Proteasome inhibitor (MG-132) treatment of mdx mice rescues the expression and membrane localization of dystrophin and dystrophin-associated proteins. Am J Pathol 163:1663-1675.

Bozzi M, Morlacchi S, Bigotti MG, Sciandra F, Brancaccio A (2009) Functional diversity of dystroglycan. Matrix Biol 28:179-187.

Bradley WG, Jenkison M (1973) Abnormalities of peripheral nerves in murine muscular dystrophy. J Neurol Sci 18:227-247.

Bragg AD, Amiry-Moghaddam M, Ottersen OP, Adams ME, Froehner SC (2006) Assembly of a perivascular astrocyte protein scaffold at the mammalian blood-brain barrier is dependent on alpha-syntrophin. Glia 53:879-890.

Cai H, Erdman RA, Zweier L, Chen J, Shaw JH 4th, Baylor KA, Stecker MM, Carey DJ, Chan YM (2007) The sarcoglycan complex in Schwann cells and its role in myelin stability. Exp Neurol 205:257-269.

Chattopadhyay S, Myers RR, Janes J, Shubayev V (2007) Cytokine regulation of MMP-9 in peripheral glia: implications for pathological processes and pain in injured nerve. Brain Behav Immun 21:561-568.

Chen YJ, Spence HJ, Cameron JM, Jess T, Ilsley JL, Winder SJ (2003) Direct interaction of beta-dystroglycan with F-actin. Biochem J 375:329-337.

Connors NC, Adams ME, Froehner SC, Kofuji P (2004) The potassium channel Kir4.1 associates with the dystrophin-glycoprotein complex via alpha-syntrophin in glia. J Biol Chem 279:28387-28392.

Court F, Alvarez J (2000) Nerve regeneration in Wld(s) mice is normalized by actinomycin D. Brain Res 867:1-8.

Court FA, Hewitt JE, Davies K, Patton BL, Uncini A, Wrabetz L, Feltri ML (2009) A laminin-2, dystroglycan, utrophin axis is required for compartmentalization and elongation of myelin segments. J Neurosci 29:3908-3919. 
Court FA, Sherman DL, Pratt T, Garry EM, Ribchester RR, Cottrell DF, Fleetwood-Walker SM, Brophy PJ (2004) Restricted growth of Schwann cells lacking Cajal bands slows conduction in myelinated nerves. Nature 431:191-195.

Di Muzio A, De Angelis MV, Di Fulvio P, Ratti A, Pizzuti A, Stuppia L, Gambi D, Uncini A (2003) Dysmyelinating sensory-motor neuropathy in merosin-deficient congenital muscular dystrophy. Muscle Nerve 27:500-506.

Dubois B, Masure S, Hurtenbach U, Paemen L, Heremans H, van den Oord J, Sciot R, Meinhardt T, Hämmerling G, Opdenakker G, Arnold B (1999) Resistance of young gelatinase B-deficient mice to experimental autoimmune encephalomyelitis and necrotizing tail lesions. J Clin Invest 104:1507-1515.

Einheber S, Zanazzi G, Ching W, Scherer S, Milner TA, Peles E, Salzer JL (1997) The axonal membrane protein Caspr, a homologue of neurexin IV, is a component of the septate-like paranodal junctions that assemble during myelination. J Cell Biol 139:1495-1506.

Feltri ML, D’Antonio M, Previtali S, Fasolini M, Messing A, Wrabetz L (1999) P0-Cre transgenic mice for inactivation of adhesion molecules in Schwann cells. Ann N Y Acad Sci 883:116-123.

Ferguson TA, Muir D (2000) MMP-2 and MMP-9 increase the neuritepromoting potential of schwann cell basal laminae and are upregulated in degenerated nerve. Mol Cell Neurosci 16:157-167.

Gazzerro E, Assereto S, Bonetto A, Sotgia F, Scarfi S, Pistorio A, Bonuccelli G, Cilli M, Bruno C, Zara F, Lisanti MP, Minetti C (2010) Therapeutic potential of proteasome inhibition in Duchenne and Becker muscular dystrophies. Am J Pathol 176:1863-1877.

Grady RM, Zhou H, Cunningham JM, Henry MD, Campbell KP, Sanes JR (2000) Maturation and maintenance of the neuromuscular synapse: genetic evidence for roles of the dystrophin-glycoprotein complex. Neuron 25:279-293.

Haenggi T, Fritschy JM (2006) Role of dystrophin and utrophin for assembly and function of the dystrophin glycoprotein complex in non-muscle tissue. Cell Mol Life Sci 63:1614-1631.

Herzog C, Has C, Franzke CW, Echtermeyer FG, Schlötzer-Schrehardt U, Kröger S, Gustafsson E, Fässler R, Bruckner-Tuderman L (2004) Dystroglycan in skin and cutaneous cells: beta-subunit is shed from the cell surface. J Invest Dermatol 122:1372-1380.

Hiscoe HB (1947) Distribution of nodes and incisures in normal and regenerated nerve fibers. Anat Rec 99:447-475.

Holt KH, Crosbie RH, Venzke DP, Campbell KP (2000) Biosynthesis of dystroglycan: processing of a precursor propeptide. FEBS Lett 468:79-83.

Ibraghimov-Beskrovnaya O, Ervasti JM, Leveille CJ, Slaughter CA, Sernett SW, Campbell KP (1992) Primary structure of dystrophin-associated glycoproteins linking dystrophin to the extracellular matrix. Nature 355:696-702.

Itoh T, Ikeda T, Gomi H, Nakao S, Suzuki T, Itohara S (1997) Unaltered secretion of beta-amyloid precursor protein in gelatinase A (matrix metalloproteinase 2)-deficient mice. J Biol Chem 272:22389-22392.

Jaros E, Jenkison M (1983) Quantitative studies of the abnormal axonSchwann cell relationship in the peripheral motor and sensory nerves of the dystrophic mouse. Brain Res 258:181-196.

Jensen TJ, Loo MA, Pind S, Williams DB, Goldberg AL, Riordan JR (1995) Multiple proteolytic systems, including the proteasome, contribute to CFTR processing. Cell 83:129-135.

Jing J, Lien CF, Sharma S, Rice J, Brennan PA, Górecki DC (2004) Aberrant expression, processing and degradation of dystroglycan in squamous cell carcinomas. Eur J Cancer 40:2143-2151.

Kherif S, Dehaupas M, Lafuma C, Fardeau M, Alameddine HS (1998) Matrix metalloproteinases MMP-2 and MMP-9 in denervated muscle and injured nerve. Neuropathol Appl Neurobiol 24:309-319.

Kidd GJ, Andrews SB, Trapp BD (1994) Organization of microtubules in myelinating Schwann cells. J Neurocytol 23:801-810.

Kopan R, Ilagan MX (2009) The canonical Notch signaling pathway: unfolding the activation mechanism. Cell 137:216-233.

La Fleur M, Underwood JL, Rappolee DA, Werb Z (1996) Basement membrane and repair of injury to peripheral nerve: defining a potential role for macrophages, matrix metalloproteinases, and tissue inhibitor of metalloproteinases-1. J Exp Med 184:2311-2326.

Lane PW, Beamer TC, Myers DD (1976) Myodystrophy, a new myopathy on chromosome 8 of the mouse. J Hered 67:135-138.

Li H, Mittal A, Makonchuk DY, Bhatnagar S, Kumar A (2009) Matrix metalloproteinase-9 inhibition ameliorates pathogenesis and improves skeletal muscle regeneration in muscular dystrophy. Hum Mol Genet 18:2584-2598.

Losasso C, Di Tommaso F, Sgambato A, Ardito R, Cittadini A, Giardina B, Petrucci TC, Brancaccio A (2000) Anomalous dystroglycan in carcinoma cell lines. FEBS Lett 484:194-198.

Matsumura K, Arai K, Zhong D, Saito F, Fukuta-Ohi H, Maekawa R, Yamada H, Shimizu T (2003) Disruption of dystroglycan axis by beta-dystroglycan processing in cardiomyopathic hamster muscle. Neuromuscul Disord 13:796-803.

Michaluk P, Kolodziej L, Mioduszewska B, Wilczynski GM, Dzwonek J, Jaworski J, Gorecki DC, Ottersen OP, Kaczmarek L (2007) Betadystroglycan as a target for MMP-9, in response to enhanced neuronal activity. J Biol Chem 282:16036-16041.

Mirowska D, Członkowska A (2001) The role of metalloprotease in pathogenesis of nervous system diseases (in Polish). Neurol Neurochir Pol 35:101-110.

Moore CJ, Winder SJ (2010) Dystroglycan versatility in cell adhesion: a tale of multiple motifs. Cell Commun Signal 8:3.

Neely JD, Amiry-Moghaddam M, Ottersen OP, Froehner SC, Agre P, Adams ME (2001) Syntrophin-dependent expression and localization of Aquaporin-4 water channel protein. Proc Natl Acad Sci USA 98:14108-14113.

Nodari A, Zambroni D, Quattrini A, Court FA, D'Urso A, Recchia A, Tybulewicz VL, Wrabetz L, Feltri ML (2007) Betal integrin activates Rac1 in Schwann cells to generate radial lamellae during axonal sorting and myelination. J Cell Biol 177:1063-1075.

Nodari A, Previtali SC, Dati G, Occhi S, Court FA, Colombelli C, Zambroni D, Dina G, Del Carro U, Campbell KP, Quattrini A, Wrabetz L, Feltri ML (2008) Alpha6beta4 integrin and dystroglycan cooperate to stabilize the myelin sheath. J Neurosci 28:6714-6719.

Occhi S, Zambroni D, Del Carro U, Amadio S, Sirkowski EE, Scherer SS, Campbell KP, Moore SA, Chen ZL, Strickland S, Di Muzio A, Uncini A, Wrabetz L, Feltri ML (2005) Both laminin and Schwann cell dystroglycan are necessary for proper clustering of sodium channels at nodes of Ranvier. J Neurosci 25:9418-9427.

O’Reilly MS, Boehm T, Shing Y, Fukai N, Vasios G, Lane WS, Flynn E, Birkhead JR, Olsen BR, Folkman J (1997) Endostatin: an endogenous inhibitor of angiogenesis and tumor growth. Cell 88:277-285.

Page-McCaw A, Ewald AJ, Werb Z (2007) Matrix metalloproteinases and the regulation of tissue remodelling. Nat Rev Mol Cell Biol 8:221-233.

Ramón y Cajal S (1933) Histology. London: Bailliere, Tindall and Cox.

Rezniczek GA, Konieczny P, Nikolic B, Reipert S, Schneller D, Abrahamsberg C, Davies KE, Winder SJ, Wiche G (2007) Plectin If scaffolding at the sarcolemma of dystrophic ( $\mathrm{mdx}$ ) muscle fibers through multiple interactions with beta-dystroglycan. J Cell Biol 176:965-977.

Roberds SL, Ervasti JM, Anderson RD, Ohlendieck K, Kahl SD, Zoloto D, Campbell KP (1993) Disruption of the dystrophin-glycoprotein complex in the cardiomyopathic hamster. J Biol Chem 268:11496-11499.

Saito F, Masaki T, Kamakura K, Anderson LV, Fujita S, Fukuta-Ohi H, Sunada Y, Shimizu T, Matsumura K (1999) Characterization of the transmembrane molecular architecture of the dystroglycan complex in schwann cells. J Biol Chem 274:8240-8246.

Saito F, Moore SA, Barresi R, Henry MD, Messing A, Ross-Barta SE, Cohn RD, Williamson RA, Sluka KA, Sherman DL, Brophy PJ, Schmelzer JD, Low PA, Wrabetz L, Feltri ML, Campbell KP (2003) Unique role of dystroglycan in peripheral nerve myelination, nodal structure, and sodium channel stabilization. Neuron 38:747-758.

Salzer JL (2003) Polarized domains of myelinated axons. Neuron 40:297-318.

Shang ZJ, Ethunandan M, Górecki DC, Brennan PA (2008) Aberrant expression of beta-dystroglycan may be due to processing by matrix metalloproteinases-2 and -9 in oral squamous cell carcinoma. Oral Oncol 44:1139-1146.

Sherman DL, Brophy PJ (2000) A tripartite nuclear localization signal in the PDZ-domain protein L-periaxin. J Biol Chem 275:4537-4540.

Sherman DL, Fabrizi C, Gillespie CS, Brophy PJ (2001) Specific disruption of a schwann cell dystrophin-related protein complex in a demyelinating neuropathy. Neuron 30:677-687.

Shubayev VI, Myers RR (2000) Upregulation and interaction of TNFalpha and gelatinases $\mathrm{A}$ and $\mathrm{B}$ in painful peripheral nerve injury. Brain Res 855:83-89.

Shubayev VI, Angert M, Dolkas J, Campana WM, Palenscar K, Myers RR 
(2006) TNFalpha-induced MMP-9 promotes macrophage recruitment into injured peripheral nerve. Mol Cell Neurosci 31:407-415.

Singh J, Itahana Y, Knight-Krajewski S, Kanagawa M, Campbell KP, Bissell MJ, Muschler J (2004) Proteolytic enzymes and altered glycosylation modulate dystroglycan function in carcinoma cells. Cancer Res 64:6152-6159.

Sottile J (2004) Regulation of angiogenesis by extracellular matrix. Biochim Biophys Acta 1654:13-22.

Straub V, Duclos F, Venzke DP, Lee JC, Cutshall S, Leveille CJ, Campbell KP (1998) Molecular pathogenesis of muscle degeneration in the deltasarcoglycan-deficient hamster. Am J Pathol 153:1623-1630.

Thompson O, Moore CJ, Hussain SA, Kleino I, Peckham M, Hohenester E, Ayscough KR, Saksela K, Winder SJ (2010) Modulation of cell spreading and cell-substrate adhesion dynamics by dystroglycan. J Cell Sci 123:118-127.

Triolo D, Cerri F, Taveggia C, Porrello E, Bolino A, Colombelli C, Feltri ML, Dina G, D'adamo P, Del Carro U, Morana P, Sherman DL, Babinet C, Quattrini A, Previtali SC (2009) Abnormal Schwann cell-axon units and myelination in vimentin-deficient mice. In: Peripheral Nerve Society Meeting (Wiley I, ed), pp 1-163. Würzburg, Germany: Journal of the Peripheral Nervous System.

Vu TH, Shipley JM, Bergers G, Berger JE, Helms JA, Hanahan D, Shapiro SD, Senior RM, Werb Z (1998) MMP-9/gelatinase B is a key regulator of growth plate angiogenesis and apoptosis of hypertrophic chondrocytes. Cell 93:411-422.

Weir ML, Oppizzi ML, Henry MD, Onishi A, Campbell KP, Bissell MJ,
Muschler JL (2006) Dystroglycan loss disrupts polarity and beta-casein induction in mammary epithelial cells by perturbing laminin anchoring. J Cell Sci 119:4047-4058.

Wrabetz L, Feltri ML (2001) Do Schwann cells stop, DR(o)P2, and roll? Neuron 30:642-644.

Wrabetz L, Feltri ML, Quattrini A, Imperiale D, Previtali S, D’Antonio M, Martini R, Yin X, Trapp BD, Zhou L, Chiu SY, Messing A (2000) P(0) glycoprotein overexpression causes congenital hypomyelination of peripheral nerves. J Cell Biol 148:1021-1034.

Wu CY, Hsieh HL, Sun CC, Yang CM (2009) IL-1beta induces MMP-9 expression via a $\mathrm{Ca}^{2+}$-dependent CaMKII/JNK/c-JUN cascade in rat brain astrocytes. Glia 57:1775-1789.

Yamada H, Saito F, Fukuta-Ohi H, Zhong D, Hase A, Arai K, Okuyama A Maekawa R, Shimizu T, Matsumura K (2001) Processing of betadystroglycan by matrix metalloproteinase disrupts the link between the extracellular matrix and cell membrane via the dystroglycan complex. Hum Mol Genet 10:1563-1569.

Zhao XL, Li GZ, Sun B, Zhang ZL, Yin YH, Tian YS, Li H, Li HL, Wang de S, Zhong D (2010) MMP-mediated cleavage of beta-dystroglycan in myelin sheath is involved in autoimmune neuritis. Biochem Biophys Res Commun 392:551-556

Zhong D, Saito F, Saito Y, Nakamura A, Shimizu T, Matsumura K (2006) Characterization of the protease activity that cleaves the extracellular domain of beta-dystroglycan. Biochem Biophys Res Commun 345: $867-871$ 